\title{
PREFACE
}

Professor Flavio Beno Siebeneichler was a visiting researcher at the Brazilian Institute of Information in Science and Technology - IBICT in the second half of 2010, invited by the research group Philosophy and Information Policy. At that time the research group was coordinated by researcher Maria Nélida González de Gómez and me. His seminaries were called "Habermas and his philosophical interests".

This collection of articles brings together the texts used in those seminars as a reference for the presentation and discussion of selected topics from the work of the German philosopher Jurgen Habermas. The texts are guides for philosophical studies, especially for philosophical studies of information. Each one of the articles was used as reference for the discussion of the topics, guiding the walk through the dense work of Habermas.

Another element to be highlighted in relation to the texts is the fact that Professor Flávio Siebeneichler used the works of Habermas in the original in German, to offer greater rigor in the use of words, concepts and theories. It should be noted that Siebeneichler is recognized as a translator of Habermas for Portuguese, including the two volumes of "Theory of communicative action".

Flávio Beno Siebeneichler is from Santa Catarina. He holds a degree in Philosophy from the State University of Rio de Janeiro and a doctorate in Theology and Science of Religion from the University of Regensburg. He is a retired professor at the Department of Philosophy of the Federal University of Rio de Janeiro. He has experience in the field of contemporary philosophy, especially in the field of Ethics, Critical Theory, Phenomenology, Hermeneutics, Systems Theory and Pragmatics.

In this context the following themes emerge in his work: communicative reason; postmetaphysical philosophy that works in connection with the human and social sciences; cooperative search for truth; interdisciplinarity; critical aesthetics; philosophy of law; world of life and system, ethics of discourse; justice; joint and several liability; perspectives of democracy in today's pluralistic societies.

In a text for the collection "Information and Democracy: the contemporary reflection of ethics and Politics ", organized by the researcher Maria Nélida and myself, Professor Siebeneichler puts the thinking of Habermas against some of the main constellations theories of contemporary thought: "The Habermasian theory breaks dialectically the relation with the traditional philosophy, configuring itself as post-Platonic thought, post Kantian and post metaphysical.

LOGEION: Filosofia da informação, Rio de Janeiro, v. 5, 2018, Edição Especial, p. 04-06. 
He shares with Niklas Luhmann and other theorists contemporary, especially those working in a pragmatic, hermeneutical and analytical line, the idea that we can no longer presuppose the existence of something sublime, ideal or superior that could serve as a point of reference for our investigations. This stems from the fact that human beings are finite and contingent, indeed, doubly contingent. In addition, they have been previously and always immersed in a world of social life that is profane, complex and intransparent, structuring and concretizing through language. So they are extremely vulnerable. "

I met Professor Siebeneichler for the time in 1989, when I was studying for a master's degree at IBICT / UFRJ, as a participant in a semester seminar offered by him at UFRJ on Habermas's work "Moral conscience and communicative action". That year Habermas himself was in Brazil to launch the translation of that work. I was guided by the researcher Maria Nélida. This seminar opened to me the doors to Habermas' discourse theory as a reference for the philosophical studies of information, particularly ethics and politics. The Habermasian theory became part of the toolbox to discuss ethics and information policy from a humanistic perspective.

I met Professor Siebeneichler again in 2008 while doing post-doctoral program at IBICT under the supervision of researcher Maria Nélida. He did one of the colloquiums of the stage, talking about the relations between Habermas and Luhmann for a better understanding of information in the world of life and systems. In this colloquy Professor Siebeneichler affirmed the possibility of thinking a discursive theory of information.

The investigation of this possibility has been the objective of my IBICT project since joining its as a researcher. Habermas has much to offer to information scholars, beginners or researchers. For example, the method of confrontation between Habermas and Luhmann opens wide avenues for thinking information as a systemic operator and as a regulator of social relations.

The relationship between Habermas and the Philosophy of information has also been explored in the Habermas and Philosophy of Information Colloquiums that the research group Philosophy and Information Policy of the IBICT has been organizing annually in Rio de Janeiro since 2010. These Colloquiums bring together experts, students and interested in the work of the German thinker and in the philosophy of information. Professor Flávio Siebeneichler participates regularly in the Colloquiums.

We hope that the publication of these eight texts by Professor Flávio Siebeneichler will contribute in a strong and effective way to the development of Philosophy of information, particularly of practical Philosophy. This is the main proposal of the magazine Logeion, of the research group Philosophy and information policy of the IBICT.

LOGEION: Filosofia da informação, Rio de Janeiro, v. 5, 2018, Edição Especial, p. 04-06. 


\section{LOGEION \\ Filosofia da Informação}

APRESENTAÇÃO

The publication of this special issue of Logeion takes place at a particularly special time in our history, in which we have conflicts about the freedom of opinion and expression, the recognition of the other, the welfare and protection of the world of the life. It's time to talk, to build understandings and agreements. It is time for the discourse among subjects. It's time to learn from Habermas. He is available.

Many thanks to Professor Flávio Siebeneichler.

Good reading!

Rio de Janeiro, November 08, 2018

Clóvis Ricardo Montenegro de Lima

Editor. 